\title{
Case Study Methodology in Research on Corporate Social Responsibility: General Publication Profiling and Identifying Research Contexts
}

DOI: http://dx.doi.org/10.12775/JCRL.2019.005

\author{
ANDRZEJ Lis \\ The Faculty of Economic Sciences and Management, \\ Nicolaus Copernicus University in Toruń, Poland \\ e-mail: andrzejlis@econ.umk.pl
}

\begin{abstract}
Purpose: The aim of the paper is to profile the scientific output in research on corporate social responsibility employing the methodology of case study. The research process is focused around the following research questions: (1) How has the research productivity in CSR case studies been changing? (2) What are the most productive contributors (countries, research institutions, source titles and scholars) to the scientific output? (3) What are the most popular contexts (geography, industry, company type) of CSR studies employing case study methodology?

Design/methodology/approach: The study employed the method of research profiling, which is categorized among bibliometric descriptive studies. The standard version of general publication profiling, comprising four aspects used to describe the scientific output in the research field i.e.: country profiling, research institution profiling, source title profiling and author profiling, was supplemented with identification of the research contexts of CSR case studies. Research profiling was supported with citation analysis and co-authorship analysis, representing science mapping methods. VOSviewer software was employed to conduct citation analysis and co-authorship analysis and visualize the findings.

Findings: The studies employing case study analysis methodology to explore corporate social responsibility issues are still within the growth phase of the research field life cycle. Research profiling of the
\end{abstract}


most productive countries, research institutions, and authors indicates the leading position of the United Kingdom. The followers are both developed nations, mainly Anglo-Saxon countries (the United States, Australia, Canada) and European continental countries (Spain, Italy, Denmark), as well as developing nations (India, Indonesia, China). Source titles profiling points out the following journals of the highest prominence publishing CSR case studies: Journal of Business Ethics, Journal of Cleaner Production, and Corporate Social Responsibility and Environmental Management. The CSR case studies are embedded in the contexts of both developed and developing nations. The mining industry is found to be the sector attracting the most attention of researchers. Other industries which are often analysed in CSR studies include: tourism and hospitality, food, banking and financial services, chemical, forestry, manufacturing, public health, fashion and textile, oil industries.

Research implications: Through bibliometric analysis of case studies in corporate social responsibility, the study contributes first and foremost to management theory. Firstly, it provides the scholars interested in the field with a detailed map identifying key contributors (countries, research institutions and authors), which may be useful for establishing research collaboration. Secondly, analysing leading source titles is of high practical value for the authors considering journals for submitting their works. Finally, discovering the most often explored contexts of CSR case studies (in regard to geography, industries, and company types), on the one hand, indicates main research interests in the field, but on the other hand may be an indication to find interesting gaps to be covered in prospective case studies.

Originality/value: The originality of the study derives from the fact that scientific output including CSR related case studies has not been mapped, so far. The employed methodology, including combination of the bibliometric descriptive approach represented by the research profiling framework and quantitative science mapping methods (citation and co-authorship analysis) creates the unique value of the study.

Paper type: Review.

Keywords: corporate social responsibility, CSR, case study, bibliometrics, research profiling.

\section{Introduction}

In his bibliometric study analysing the employment of case study research methodology in management studies, Lis (2018, p. 179) observes that "[t]he increasing need for highly contextualized studies in the field of management results in the growing interest of researchers in qualitative methods, and case study methodology in particular. Case 
study analysis seems to be one of the most suitable research approaches to explore research problems in a given context”. What is the situation in this regard in the research field focused on corporate social responsibility (CSR) issues? Are case studies often used to explore CSR approaches and practices?

Corporate social responsibility makes up a rapidly growing research field. As of 08 November 2020, in the Scopus database, there were indexed 12,107 publications including expressions 'CSR' or 'corporate social responsibility' in their titles (title search). Among them, we found 819 items comprising the keyword 'case stud*' in their titles, keywords or abstracts (topic search). Thus, we may assume that case study is a research method employed by around $7 \%$ of highly quality papers dealing with CSR issues. Nevertheless, this body of knowledge has never been mapped with the use of bibliometric methodology. Within the identified corpus, the topic search indicates only two publications comprising phrases 'bibliometric', 'scientometric' or 'informetric'. In fact, none of them provides the mapping of the collection of CSR publications employing case study methodology. Exploring the corpus of literature on CSR and human resource management, Herrera and de las Heras-Rosas (2020) notice that numerous case studies have been developed in each of these areas. Preslmayer and associates (2018) conduct a citation analysis of publication on CSR in family firms and concluding their findings they call for more case studies analyses in the field.

In response to the aforementioned gap in the body of knowledge, the aim of the paper is to profile the scientific output in research on corporate social responsibility employing the methodology of case study. The research process is focused around the following research questions: (1) How has the research productivity in CSR case studies been changing? (2) What are the most productive contributors (countries, research institutions, source titles and scholars) to the scientific output? (3) What are the most popular contexts (geography, industry, company type) of CSR studies employing case study methodology? The remainder of the paper is structured as follows: Firstly, the method of study and the research sampling process are explained. Secondly, the research productivity in CSR case studies is analysed. Thirdly, the findings from general publication profiling of the literature corpus are presented. Fourthly, the geographical and industrial contexts of CSR case studies are explored. 


\section{Method of study}

The study employs the method of research profiling (Porter et al., 2002), which is categorized among bibliometric descriptive studies, and has proved to be effective in mapping the CSR related areas of research such as: CSR intersections with leadership (Lis \& Cegliński, 2017), sustainable enterprises and organisations (Sudolska \& Lis, 2018) or sustainable innovations (Sudolska et al., 2019). In this study, in particular, the first component of the methodology, i.e. general publication profiling, is used. The standard version of general publication profiling comprises four aspects to describe the scientific output in the research field i.e.: country profiling, research institution profiling, source title profiling and author profiling (Martinez et al., 2012). For the purposes of this study, they were supplemented with identification of research contexts (cf. Figure 1).

Standard Items
- Country profiling
- Research institution profiling
- Source title profiling
- Author profiling
Customized Items
- Research contexts

Figure 1. Structure of the extended general publication profiling Source: own study based on Martinez et al. (2012, p. 660).

Data for analysis were retrieved from the Scopus database, considered as a reliable source bibliometric data comprising high quality research publications (Mongeon \& Paul-Hus, 2016; Schotten et al., 2017; Scopus Content Coverage Guide 2020, 2020; Zhu \& Liu, 2020). For the purposes of research sampling process, the following query was conducted on 08 November 2020: Title Search ('CSR' or 'corporate social responsibility') AND Topic Search ('case stud*'). The truncation technique was used to include all the alterations of the phrase 'case study'. As a result 819 publications were retrieved. These publications are distributed over 24 subject areas defined by Scopus. A variety of subject areas represented in the sample confirms the multidisciplinary character of CSR related studies. Certainly, Business, Management and 
Accounting (including 558 items) is found to be the most populated subject area, followed by: Social Sciences (315), Economics, Econometrics and Finance (235), and Environmental Science (119). Journal articles (588) and publications written in English (806) constitute the majority of the sample in regard to the respective categories. The detailed characteristics of the sample are provided in Table 1.

Table 1. Research sample characteristics

\begin{tabular}{|c|c|}
\hline Category & Items (number) \\
\hline Subject area & $\begin{array}{l}\text { Business, Management and Accounting (558); Social Sciences } \\
\text { (315); Economics, Econometrics and Finance (235); Environmental } \\
\text { Science (119); Arts and Humanities (81); Engineering (60); Energy } \\
\text { (47); Decision Sciences (39); Computer Science (33); Earth and } \\
\text { Planetary Sciences (24); Agricultural and Biological Sciences (20); } \\
\text { Medicine (15); Psychology (12); Mathematics (10); Chemical } \\
\text { Engineering (4); Health Professions (3); Pharmacology, Toxicology } \\
\text { and Pharmaceutics (3); Biochemistry, Genetics and Molecular } \\
\text { Biology (2); Chemistry (2); Materials Science (2); Nursing (2); } \\
\text { Multidisciplinary (1); Neuroscience (1); Physics and Astronomy (1) }\end{array}$ \\
\hline $\begin{array}{l}\text { Document } \\
\text { type }\end{array}$ & $\begin{array}{l}\text { Article (588); Book Chapter (96); Conference Paper (57); Review } \\
\text { (52); Book (21); Note (2); Abstract Report (1); Erratum (1); } \\
\text { Undefined (1) }\end{array}$ \\
\hline Source type & $\begin{array}{l}\text { Journal (643); Book (100); Book Series (39); Conference } \\
\text { Proceedings (37) }\end{array}$ \\
\hline Language & $\begin{array}{l}\text { English (806); Spanish (13); Ukrainian (2); Chinese (1); Croatian } \\
\text { (1); French (1); Italian (1); Portuguese (1); Russian (1) }\end{array}$ \\
\hline
\end{tabular}

Source: own study based on data retrieved from Scopus (access on 08 November 2020).

Research profiling was supported with citation analysis and co-authorship analysis, representing science mapping methods (Zupic \& Čater, 2015). VOSviewer software (van Eck \& Waltman, 2010, 2018) was employed to conduct citation analysis and co-authorship analysis and visualize the findings. The following parameters were used in analysis: (1) normalization method: association strength; (2) layout (default values): attraction (citation and co-authorship analysis: 2); repulsion (citation analysis: 1; co-authorship analysis:-1). Besides the number of citations received by a publication, the parameter of the normalized number of citations was used in analysis. "The normalized number of citations of a document equals the number of citations of the 
document divided by the average number of citations of all documents published in the same year and included in the data that is provided to VOSviewer. The normalization corrects for the fact that older documents have had more time to receive citations than more recent documents" (van Eck \& Waltman, 2018, p. 25).

\section{Research productivity}

The earliest publication in the research sample dates back to 1989 (Brice \& Wegner, 1989). Nevertheless, the constant presence of case studies among the CSR publications indexed in Scopus has been reported since 2003. In this period, a growing trend is observed in regard to scientific productivity in CSR case studies, taking into account both the number of publications (Figure 2) and the number of received citations (Figure 3). Between 2003 and 2019, the number of published CSR case studies increased from 2 to 95 . The number of citations grew from 9 in 2005 to 2,265 in 2020. As the numbers of publications and citations they receive may be used as measures indicating development of the research field (Czakon, 2011), it seems to be enough evidence to hypothesize that the studies employing case study analysis methodology to explore corporate social responsibility issues are still within the growth phase of the research field life cycle.

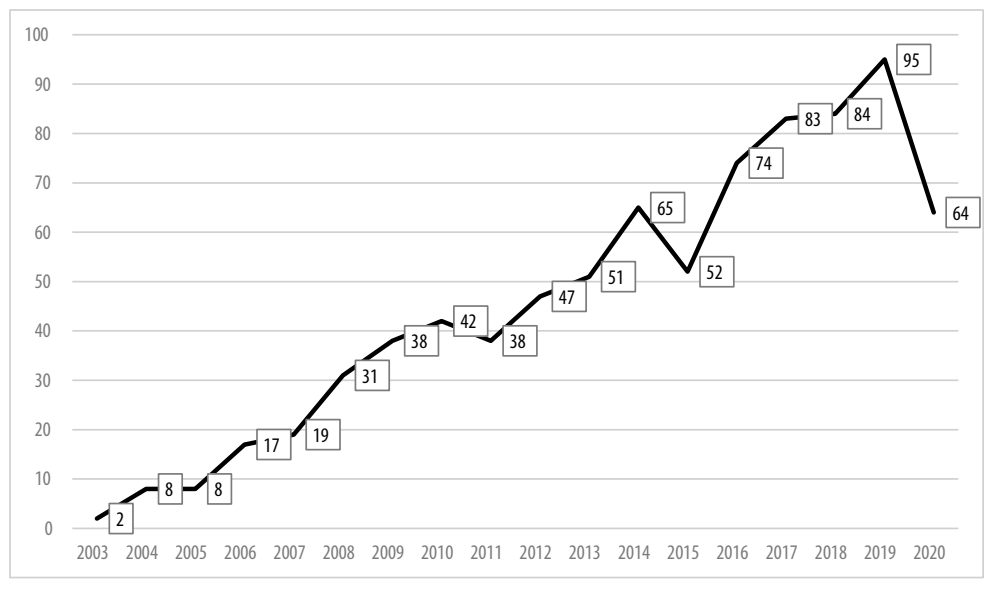

Figure 2. Scientific productivity of case studies in corporate social responsibility [number of publications]

Source: own study based on data retrieved from Scopus (access on 08 November 2020). 


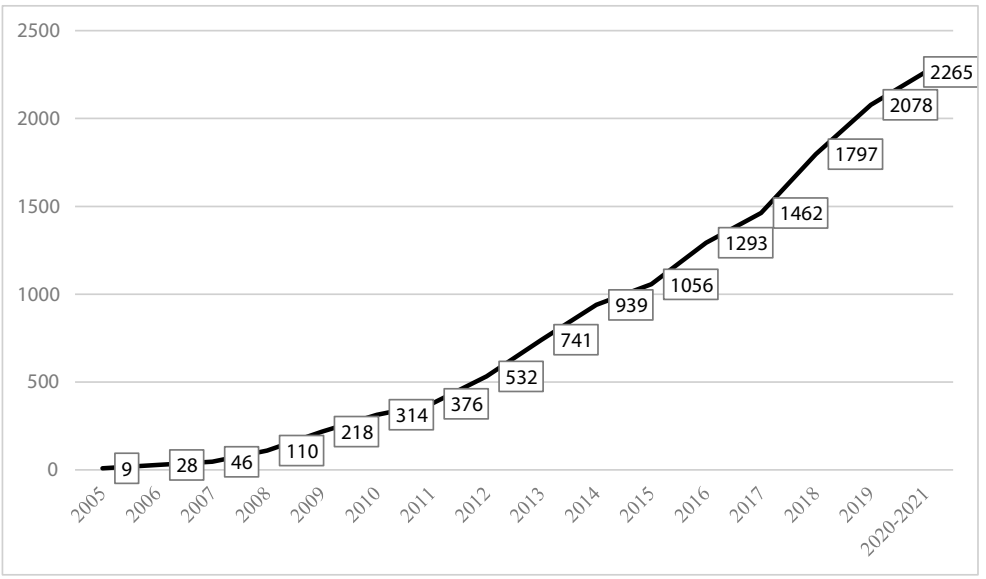

Figure 3. Scientific productivity of case studies in corporate social responsibility [number of citations]

Source: own study based on data retrieved from Scopus (access on 08 November 2020).

In order to assess the pace of scientific productivity growth in the field, the percentage changes in the number publications in 2010-2020 were compared between CSR case studies and all CSR publications indexed in the Scopus database (title search). The findings displayed in Figure 4 indicate that the growth rate for case studies was usually lower

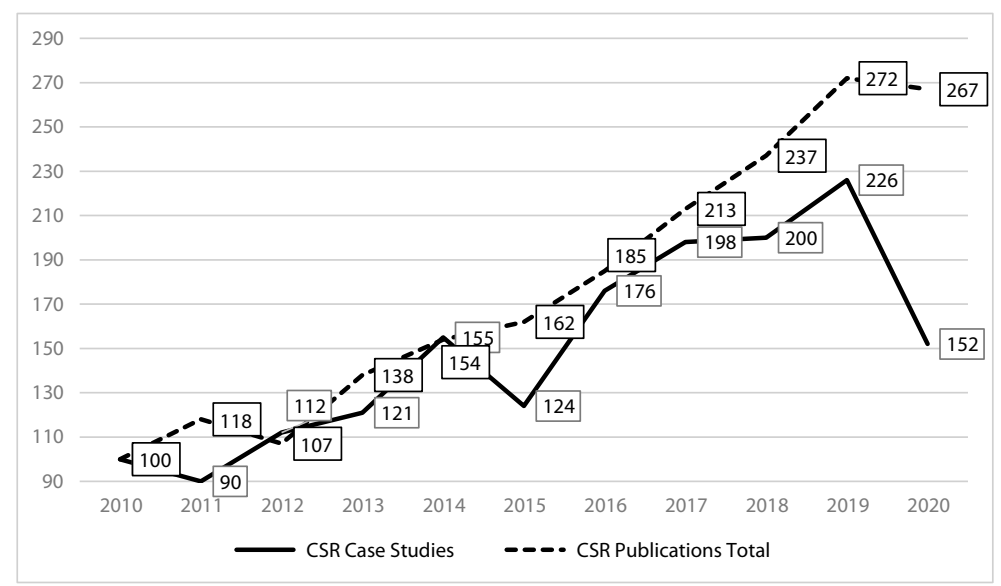

Figure 4. Growth rate of scientific productivity measured by the number of publications [\%; 2010=100\%]

Source: own study based on data retrieved from Scopus (access on 08 November 2020). 
that the one for total CSR publications. The widening of the gap has been particularly noticed since 2015 .

\section{Country profiling}

Scientific production in the research sample is distributed over 91 countries. Taking into account the number of publications, among the countries contributing to CSR case studies, there are 27 nations with minimum 10 publications, and 10 countries with at least 25 items. The United Kingdom with 150 works is found to be the unquestioned leader. Its contribution makes $18.3 \%$ of total research production in the research sample. Among the followers, there are both developed nations, mainly Anglo-Saxon countries (the United States, Australia, Canada) and European continental countries (Spain, Italy, Denmark), as well as developing nations (India, Indonesia, China). In regard to the number of received citations, the leading position of the United Kingdom is even more prominent. Its contribution with 4,964 citations (normalized citations 217.46) makes more than one third (37.4\%) of all citations received by the items in the research sample. Other nations, whose publications are often cited, include: the United States $(1,616$ citations; 12.5\%; 74.07 normalized citations) and Denmark (1,015; 7.7\%; 52.84). The highest h-index is achieved by the United Kingdom (34), Australia (16) and the United States (15). The detailed data on the top 10 most countries in producing CSR cases studies are presented in Table 2.

Among all the analysed nations, there are 33 countries which contributed with minimum 5 publications and simultaneously received at least 50 citations, which are taken for citation analysis (Figure 5). The citation analysis of research production in CSR case studies points out the United Kingdom, the United States, Denmark, Spain, Italy, Australia, the Netherlands, and Canada among the most influential contributors. In this regard, the competitive position of developing nations seems to be clearly weaker comparing to developed countries. In order to mitigate the bias of citation analysis toward older documents, normalized citations (cf. Table 2) were taken into analysis as well. This analysis confirms the leading role of publications produced in the United Kingdom and other developed nations (e.g. Australia, Italy) included in the ranking of the most productive countries. Nevertheless, it is worth 
Table 2. The top 10 most productive countries in CSR case studies

\begin{tabular}{llllllll}
\hline \multirow{2}{*}{ No. } & \multirow{2}{*}{ Country } & \multicolumn{2}{l}{ Publications } & \multicolumn{2}{l}{ Citations } & & \\
\cline { 3 - 8 } & & $\mathbf{N}$ & $\mathbf{\%}$ & $\mathbf{N}$ & $\mathbf{\%}$ & $\mathbf{h}$-index & Norm. \\
\hline 1. & United Kingdom & 150 & 18.3 & 4964 & 37.4 & 34 & 217.46 \\
\hline 2. & United States & 65 & 7.9 & 1616 & 12.2 & 15 & 74.07 \\
\hline 3. & Spain & 51 & 6.2 & 830 & 6.3 & 13 & 55.20 \\
\hline 4. & Australia & 48 & 5.9 & 770 & 5.8 & 16 & 63.63 \\
\hline 5. & Italy & 42 & 5.1 & 780 & 5.9 & 11 & 60.03 \\
\hline 6. & India & 38 & 4.6 & 194 & 1.5 & 6 & 12.67 \\
\hline 7. & Denmark & 31 & 3.8 & 1015 & 7.7 & 12 & 52.84 \\
\hline 8. & Indonesia & 29 & 3.5 & 51 & 0.4 & 4 & 9.49 \\
\hline 9. & China & 28 & 3.4 & 296 & 2.2 & 8 & 31.57 \\
\hline 10. & Canada & 26 & 3.2 & 647 & 4.9 & 10 & 37.89 \\
\hline
\end{tabular}

Source: own study based on data retrieved from Scopus (access on 08 November 2020).

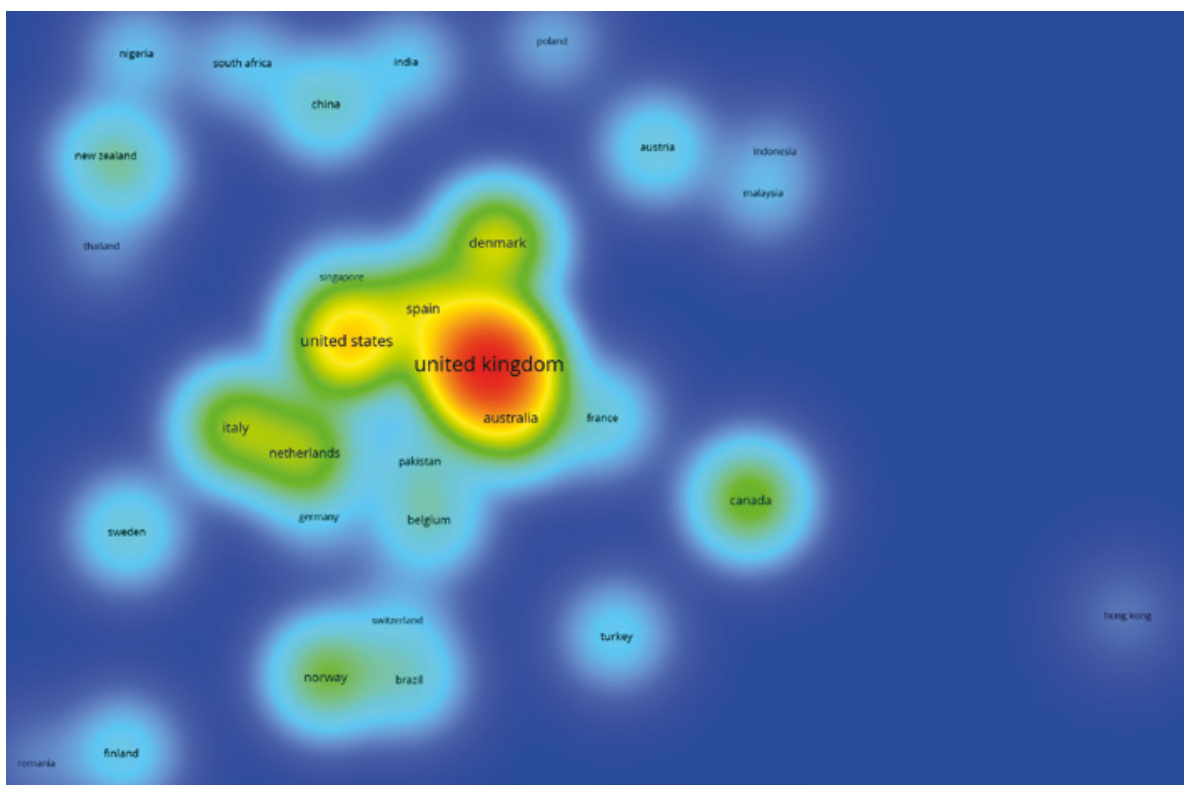

Figure 5. Item density visualization of country citation analysis [weights: citations]

Source: own study based on data retrieved from Scopus (access on 08 November 2020) and analysed with VOSviewer. 
noticing that the representatives of emerging economies such as China, and even India and Indonesia, achieve better results while taking into account normalized citations instead of the number of citations only. This may be an indication of improvement in the position of research output of these countries in recent years.

\section{Research institution profiling}

The dominant position of the United Kingdom in producing CSR case studies is confirmed by analysis of the most productive research institutions. Among top 12 contributors in this category, there are 9 British universities. Nevertheless, two Danish higher education institutions are particularly worth mentioning i.e. Copenhagen Business School (the leader of the ranking with 17 publications), and Aarhus University (the 2 top contributor, ex aequo with the University of Gloucestershire, the UK; 10 publications). Within this ranking, only one institution from developing nations is reported (Hongkong Polytechnic University). Taking into account the number of received citations, Cardiff University (784 citations; 5.9\%) and Copenhagen Business School (741; 5.6\%) are worth noticing. The detailed data are presented in Table 3.

Table 3. The top 10 most productive research institutions in CSR case studies

\begin{tabular}{llllllll}
\hline \multirow{2}{*}{ No. } & Institution & Country & \multicolumn{2}{l}{ Publications } & \multicolumn{2}{l}{ Citations } & \\
\cline { 4 - 8 } & & $\mathbf{N}$ & $\mathbf{\%}$ & $\mathbf{N}$ & $\mathbf{\%}$ & h-index \\
\hline 1. & $\begin{array}{l}\text { Copenhagen } \\
\text { Business School }\end{array}$ & Denmark & 17 & 2.1 & 741 & 5.6 & 7 \\
\hline 2-3. & $\begin{array}{l}\text { University of } \\
\text { Gloucestershire }\end{array}$ & $\begin{array}{l}\text { United } \\
\text { Kingdom }\end{array}$ & 10 & 1.2 & 253 & 1.9 & 7 \\
\hline 2-3. & $\begin{array}{l}\text { Aarhus } \\
\text { Universitet }\end{array}$ & Denmark & 10 & 1.2 & 142 & 1.1 & 6 \\
\hline 4. & $\begin{array}{l}\text { University } \\
\text { of South Wales }\end{array}$ & $\begin{array}{l}\text { United } \\
\text { Kingdom }\end{array}$ & 9 & 1.1 & 253 & 1.9 & 7 \\
\hline 5. & $\begin{array}{l}\text { University of } \\
\text { Birmingham }\end{array}$ & $\begin{array}{l}\text { United } \\
\text { Kingdom }\end{array}$ & 8 & 1.0 & 86 & 0.6 & 4 \\
\hline 6. & $\begin{array}{l}\text { Cardiff } \\
\text { University }\end{array}$ & $\begin{array}{l}\text { United } \\
\text { Kingdom }\end{array}$ & 7 & 0.9 & 784 & 5.9 & 6 \\
\hline
\end{tabular}


Table 3. Continued

\begin{tabular}{llllllll}
\hline \multirow{2}{*}{ No. } & Institution & Country & \multicolumn{2}{l}{ Publications } & \multicolumn{2}{c}{ Citations } & \\
\cline { 5 - 8 } & & $\mathbf{N}$ & $\mathbf{\%}$ & $\mathbf{N}$ & $\mathbf{\%}$ & h-index \\
\hline 7-12. & $\begin{array}{l}\text { University of } \\
\text { Manchester }\end{array}$ & $\begin{array}{l}\text { United } \\
\text { Kingdom }\end{array}$ & 6 & 0.7 & 152 & 1.1 & 3 \\
\hline 7-12. & $\begin{array}{l}\text { Hongkong Polytechnic } \\
\text { University }\end{array}$ & $\begin{array}{l}\text { Hongkong/ } \\
\text { China }\end{array}$ & 6 & 0.7 & 19 & 0.1 & 2 \\
\hline $7-12$. & $\begin{array}{l}\text { University } \\
\text { of Reading }\end{array}$ & $\begin{array}{l}\text { United } \\
\text { Kingdom }\end{array}$ & 6 & 0.7 & 218 & 1.6 & 3 \\
\hline $7-12$. & $\begin{array}{l}\text { University of } \\
\text { Nottingham }\end{array}$ & $\begin{array}{l}\text { United } \\
\text { Kingdom }\end{array}$ & 6 & 0.7 & 99 & 0.7 & 5 \\
\hline $7-12$. & $\begin{array}{l}\text { Brunel University } \\
\text { London }\end{array}$ & $\begin{array}{l}\text { United } \\
\text { Kingdom }\end{array}$ & 6 & 0.7 & 423 & 3.2 & 6 \\
\hline $7-12$. & $\begin{array}{l}\text { University } \\
\text { of Surrey }\end{array}$ & $\begin{array}{l}\text { United } \\
\text { Kingdom }\end{array}$ & 6 & 0.7 & 59 & 0.4 & 4 \\
\hline
\end{tabular}

Source: own study based on data retrieved from Scopus (access on 08 November 2020).

\section{Source title profiling}

Case studies in CSR included in the sample are distributed over 465 source titles. There are noticed 16 sources, which meet the threshold of minimum 5 publications. Taking into account the number of published CSR cases, the source titles of the first choice are: Journal of Business Ethics (50 publications), Strategic Direction (33), Social Responsibility Journal (22), Sustainability Switzerland (21), and Corporate Social Responsibility and Environmental Management (20). In regard to the numbers of received citations and normalized citations, the leaders are: Journal of Business Ethics (3,058 citations; 23.1\%; 142.12 normalized citations), Journal of Cleaner Production (1,117; 8.4\%; 49.19), Corporate Social Responsibility and Environmental Management (786; 5.9\%; 43.09). 25 source titles, the publications of which received at least 100 citations, are included in citation analysis (cf. Figure 6), which confirms the leading position of the three aforementioned journals. Moreover, a noticeable level of normalized citations of Sustainability Switzerland $(123 ; 0.9 \%$; 46.12) may be an indication of the growing position of the journal in recent years. The detailed data for source title profiling are presented in Table 4. 
Table 4. The top 10 source titles of the first choice for publishing CSR case studies

\begin{tabular}{|c|c|c|c|c|c|c|c|}
\hline \multirow{2}{*}{ No. } & \multirow{2}{*}{ Source title } & \multicolumn{2}{|c|}{ Publications } & \multicolumn{2}{|c|}{ Citations } & \multirow[b]{2}{*}{ h-index } & \multirow[b]{2}{*}{ Norm } \\
\hline & & $\mathbf{N}$ & $\%$ & $\mathbf{N}$ & $\%$ & & \\
\hline 1. & Journal of Business Ethics & 50 & 6.1 & 3058 & 23.1 & 25 & 142.12 \\
\hline 2. & Strategic Direction & 33 & 4.0 & 6 & 0.0 & 2 & - \\
\hline 3. & Social Responsibility Journal & 22 & 2.7 & 202 & 1.5 & 9 & 13.22 \\
\hline 4. & Sustainability Switzerland & 21 & 2.6 & 123 & 0.9 & 7 & 46.12 \\
\hline 5. & $\begin{array}{l}\text { Corporate Social } \\
\text { Responsibility and } \\
\text { Environmental Management }\end{array}$ & 20 & 2.4 & 786 & 5.9 & 12 & 43.09 \\
\hline 6. & Corporate Communications & 13 & 1.6 & 168 & 1.3 & 6 & 16.18 \\
\hline 7. & $\begin{array}{l}\text { Corporate Governance } \\
\text { Bingley }\end{array}$ & 10 & 1.2 & 78 & 0.6 & 7 & - \\
\hline $8-9$. & Corporate Governance & 9 & 1.1 & 169 & 1.3 & 7 & 4.06 \\
\hline $8-9$. & Journal of Cleaner Production & 9 & 1.1 & 1117 & 8.4 & 8 & 49.19 \\
\hline 10. & $\begin{array}{l}\text { Critical Studies on Corporate } \\
\text { Responsibility Governance } \\
\text { and Sustainability }\end{array}$ & 8 & 1.0 & 16 & 0.1 & 2 & - \\
\hline
\end{tabular}

Source: own study based on data retrieved from Scopus (access on 08 November 2020).

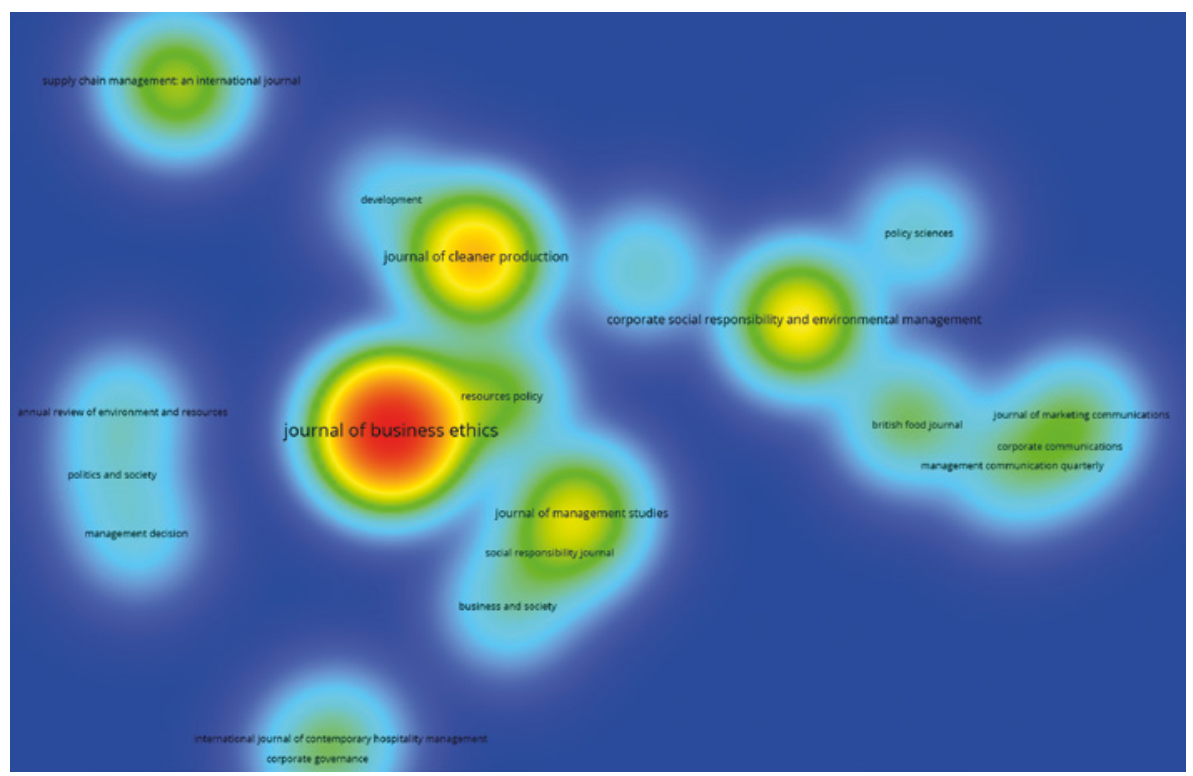

Figure 6. Item density visualization of source titles citation analysis [weights: citations] Source: own study based on data retrieved from Scopus (access on 08 November 2020) and analysed with VOSviewer. 


\section{Author profiling}

In total, 1,622 scholars authored the publications comprising the research sample. In regard to the number of published works, the most prolific authors are D. Comfort and P. Jones from the University of Gloucestershire, the United Kingdom, D. Hillier representing the University of Strathclyde, the United Kingdom, and A. Lindgreen and P. Lund-Thomsen affiliated at Copenhagen Business School, Denmark (cf. Table 5).

Table 5. The top 5 most prolific authors in CSR case studies

\begin{tabular}{|c|c|c|c|c|c|c|c|c|c|}
\hline \multirow{2}{*}{ No. } & \multirow{2}{*}{ Author } & \multirow{2}{*}{ Institution } & \multirow{2}{*}{ Country } & \multicolumn{6}{|c|}{ Publications Citations } \\
\hline & & & & $\mathbf{N}$ & $\%$ & $\mathbf{N}$ & $\%$ & h-index & Norm. \\
\hline 1. & Comfort, D. & $\begin{array}{l}\text { University of } \\
\text { Gloucestershire }\end{array}$ & $\begin{array}{l}\text { United } \\
\text { Kingdom }\end{array}$ & 10 & 1.2 & 253 & 1.9 & 7 & 5.51 \\
\hline 2. & Jones, $\mathrm{P}$. & $\begin{array}{l}\text { University of } \\
\text { Gloucestershire }\end{array}$ & $\begin{array}{l}\text { United } \\
\text { Kingdom }\end{array}$ & 10 & 1.2 & 253 & 1.9 & 7 & 5.51 \\
\hline 3. & Hillier, D. & $\begin{array}{l}\text { University of } \\
\text { Strathclyde }\end{array}$ & $\begin{array}{l}\text { United } \\
\text { Kingdom }\end{array}$ & 10 & 1.2 & 253 & 1.9 & 7 & 5.51 \\
\hline 4. & $\begin{array}{l}\text { Lindgreen, } \\
\text { A. }\end{array}$ & $\begin{array}{l}\text { Copenhagen } \\
\text { Business School }\end{array}$ & Denmark & 9 & 1.1 & 352 & 2.7 & 6 & 12.81 \\
\hline 5. & $\begin{array}{l}\text { Lund- } \\
\text { Thomsen, P. }\end{array}$ & $\begin{array}{l}\text { Copenhagen } \\
\text { Business School }\end{array}$ & Denmark & 7 & 0.9 & 121 & 0.9 & 3 & 7.95 \\
\hline
\end{tabular}

Source: own study based on data retrieved from Scopus (access on 08 November 2020).

There are identified 27 authors, whose publications were cited at least 200 times. The citation analysis of authors' contribution indicates the following scholars whose works seem to be the most influential in the research field: H. Jenkins (1,102 citations; 9.30 normalized citations) from Cardiff University, the United Kingdom, N. Yakovleva (566; 10.45) from Newcastle University, the United Kingdom, J.P. Doh (538; 4.41) from Villanova University, the United States, T.R. Guay (538; 4.41) from Pennsylvania State University, the United States, M. Andersen (352; 7.98), T. Skjoett-Larsen (352; 7.98), A. Lindgreen (350; 12.81), F. Cilberti (337; 12.63), P. Pontrandolfo (337; 12.63), J.M. Lozano (299; 2.45), D. Comfort (253; 5.51). Analysing the contributions made by scholars, co-authorship is an important aspect. Figure 7 presents the 


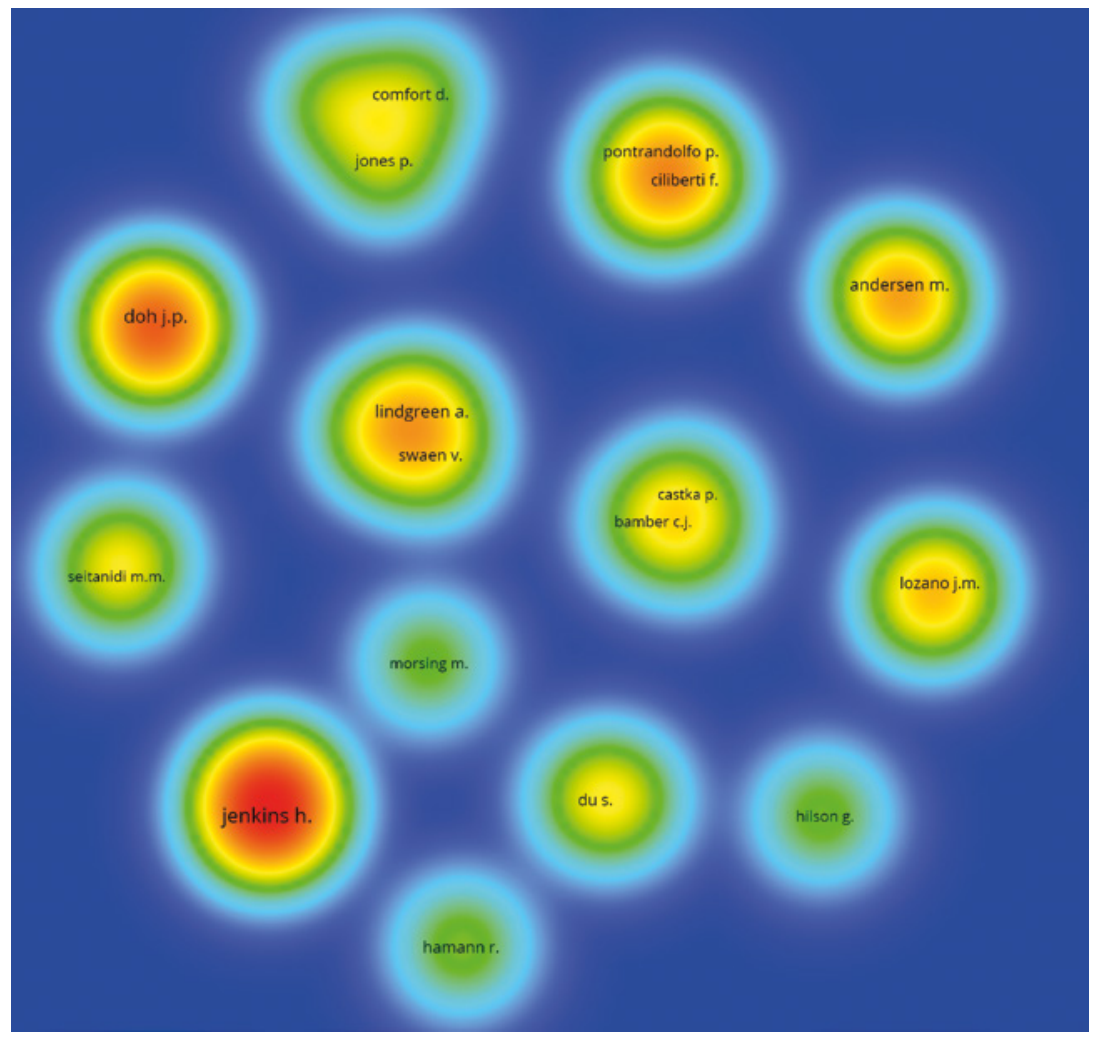

Figure 7. Item density visualization of co-authorship analysis [weights: citations] Source: own study based on data retrieved from Scopus (access on 08 November 2020) and analysed with VOSviewer.

item density visualization of co-authorship analysis (using the same selection criteria as in the case of citation analysis). Among the leading authors, besides works written individually related to CSR in the mining industry (Jenkins, 2004) and in SMEs (Jenkins, 2006), H. Jenkins collaborated with N. Yakovleva to produce another case study embedded in the context of the mining industry (Jenkins \& Yakovleva, 2006). J.P. Doh and T.R. Guay co-authored the case exploring “[c]orporate social responsibility, public policy and NGO activism in Europe and the United States” (Doh \& Guay, 2006). Andersen and Skjoett-Larsen (2009), in their common study of the Ikea case, explore corporate social responsibility in global supply chains. F. Ciliberti, P. Pontradolfo and B. Scozzi analyse five Italian SMEs to study "the practices adopted and 
difficulties experiences by [...] SMEs to transfer socially responsible behaviors to supplier that operate in developing countries" (Ciliberti et al., 2008). D. Comfort, P. Jones and D. Hillier wrote together a bunch of articles dealing with the cases in the hospitality industry (Jones et al., 2006b), the retailing industry (including food and fashion) (Jones et al., 2006a, 2007a, 2007b, 2008, 2012; Jones, Comfort, \& Hillier, 2005; Jones, Comfort, Hillier, et al., 2005; Jones \& Comfort, 2019), and the gambling industry (Jones et al., 2009).

\section{Research contexts}

As case studies are deeply embedded in research contexts, analysing these contexts seems to be a valuable component supplementing the traditional structure of research profiling methodology. The following tables present the frequency of keywords cited in the publications comprising the research sample related to the geographical context (Table 6), the industrial context (Table 7) and the type of analysed companies (Table 8).

Regarding the geographical context, CSR case studies most often refer to developing countries in Asia, Africa and Latin America, but developed countries e.g. Australia and European nations are represented among them as well. The following countries are listed among the top high-frequency keywords: China (16 occurrences), India (12), Brazil (10), the United Kingdom (10), Australia (9), Bangladesh (9), and Spain (8). What are the reasons for such a structure of geographical distribution of CSR case studies? Firstly, the interest in analysing CSR practices in developing nations may be motivated by challenges and problems encountered in these regions with employment of social responsibility assumptions and ideas. Secondly, some similarities may be observed between the ranking of the most productive countries in CSR case studies (Table 2) and the list of high-frequency keywords representing the geographical contexts of research (Table 6). It seems to be quite natural that authors select the cases for analysis from the countries they come from, as they better know the context of a country and have an easier access to data and respondents. This may be the explanation for a balanced mix of cases from both developed and developing countries within the sample. 
Table 6. Geographical contexts in CSR case studies (ranked by the number of occurrences)

\begin{tabular}{ll}
\hline Keyword & N \\
\hline Developing countries & 17 \\
\hline China & 16 \\
\hline India & 12 \\
\hline Africa & 10 \\
\hline Brazil & 10 \\
\hline Developing world & 10 \\
\hline United Kingdom & 10 \\
\hline Australia & 9 \\
\hline Bangladesh & 9 \\
\hline Spain & 8 \\
\hline Emerging markets & 7 \\
\hline Europe & 7 \\
\hline Indonesia & 6 \\
\hline
\end{tabular}

\begin{tabular}{ll}
\hline Keyword & N \\
\hline Nigeria & 6 \\
\hline Thailand & 6 \\
\hline Asia & 5 \\
\hline Ghana & 5 \\
\hline Latin America & 5 \\
\hline Slovenia & 5 \\
\hline Sub-Saharan Africa & 5 \\
\hline Tanzania & 5 \\
\hline Angola & 5 \\
\hline Canada & 4 \\
\hline Egypt & 4 \\
\hline Eurasia & 4 \\
\hline Greece & 4 \\
\hline
\end{tabular}

\begin{tabular}{ll}
\hline Keyword & N \\
\hline Mexico & 4 \\
\hline Pakistan & 4 \\
\hline Turkey & 4 \\
\hline Denmark & 3 \\
\hline Korea & 3 \\
\hline Malawi & 3 \\
\hline Malaysia & 3 \\
\hline Russia & 3 \\
\hline UK & 3 \\
\hline United States & 3 \\
\hline Zambia & 3 \\
\hline
\end{tabular}

Source: own study based on data retrieved from Scopus (access on 08 November 2020).

In regard to the industrial context, the mining industry seems to be the sector attracting the most attention of researchers. Other industries which are often analysed in CSR studies include: tourism and hospitality, food, banking and financial services, chemical, forestry, manufacturing, public health, fashion and textile, oil industries. The full catalogue of the most cited industrial contexts in CSR case studies is provided in Table 7. What are the reasons for particular interest of researchers in these industries? It may be hypothesized that the attention of scholars is given to extraction and manufacturing industries, which have negative influence on the environment and/or used to be blamed for labour malpractices, e.g. mining, oil, chemical, textile and fashion, tourism and hospitality. The food industry and forestry are of high importance both for protection of the natural environment and human health. Public health and education are crucial for human well-being and development of individuals and society.

In regard to the company type, CSR case studies are most often interested in international/multinational companies, small and medium enterprises (SMEs) and family businesses (cf. Table 8). The context of international/multinational companies gives the opportunity to compare and contrast the approaches and practices related to corporate social 
Table 5. Industrial contexts in CSR case studies (ranked by the number of occurrences)

\begin{tabular}{|c|c|c|c|c|c|}
\hline Keyword & $\mathbf{N}$ & Keyword & $\mathbf{N}$ & Keyword & $\mathbf{N}$ \\
\hline Mining & 20 & Banking sector & 4 & Higher education & 3 \\
\hline Mining industry & 17 & Banks & 4 & Manufacture & 3 \\
\hline Tourism & 10 & Chemical industry & 4 & Oil industry & 3 \\
\hline Commerce & 8 & Forestry & 4 & Retailers & 3 \\
\hline Food industry & 8 & Manufacturing & 4 & Retailing & 3 \\
\hline Hotels & 8 & Public health & 4 & Sales & 3 \\
\hline Hotel industry & 6 & Textile industry & 4 & Telecommunications & 3 \\
\hline Hospitality industry & 5 & Fashion & 3 & Tobacco industry & 3 \\
\hline Banking & 4 & Financial services & 3 & & \\
\hline
\end{tabular}

Source: own study based on data retrieved from Scopus (access on 08 November 2020).

responsibility between the countries, and the home and host nations. SMEs and family businesses may be attractive candidates for CSR cases because corporate social responsibility issues have been traditionally studied from the perspective of large corporations.

Table 8. Types of companies in CSR case studies (ranked by the number of occurrences)

\begin{tabular}{ll}
\hline Keyword & $\mathbf{N}$ \\
\hline SMEs & 11 \\
\hline Multinational companies & 9 \\
\hline International business & 5 \\
\hline
\end{tabular}

\begin{tabular}{ll}
\hline Keyword & N \\
\hline SME & 5 \\
\hline Family business & 4 \\
\hline Small and medium enterprises & 3 \\
\hline
\end{tabular}

Source: own study based on data retrieved from Scopus (access on 08 November 2020).

\section{Conclusions}

In response to the first study question (How has the research productivity in CSR case studies been changing?), a growing trend has been observed in 2003-2020 in regard to scientific productivity in CSR case studies, taking into account both the number of publications and the number of received citations. It seems to be enough evidence to 
hypothesize that the studies employing case study analysis methodology to explore corporate social responsibility issues are still within the growth phase of the research field life cycle. Moreover, the growth rate for case studies was usually lower that the one for total CSR publications, which opens a free space for increasing intensity of employing this methodology to explore corporate social responsibility issues.

In response to the second study question (What are the most productive contributors to the scientific output?), leading countries, research institutions, source titles and scholars have been profiled. Among the countries, which contribute most to production of CSR case studies, the United Kingdom is found to be the unquestioned leader. The followers are both developed nations, mainly AngloSaxon countries (the United States, Australia, Canada) and European continental countries (Spain, Italy, Denmark), as well as developing nations (India, Indonesia, China). In regard to citation analysis, the competitive position of developing nations seems to be clearly weaker comparing to developed countries but there are some indications of improvement in recent years. The dominant position of the United Kingdom in producing CSR case studies is confirmed by analysis of the most productive research institutions. Among top 12 contributors in this category, there are 9 British universities. Nevertheless, Copenhagen Business School is the leader of the ranking. Journal of Business Ethics is found to be the leading source title taking into account both the numbers of publications and received citations. Other prominent journals publishing CSR case studies are: Journal of Cleaner Production, and Corporate Social Responsibility and Environmental Management. The most prolific authors are: D. Comfort and P. Jones from the University of Gloucestershire, the United Kingdom, D. Hillier representing the University of Strathclyde, the United Kingdom and A. Lindgreen and P. Lund-Thomsen affiliated at Copenhagen Business School, Denmark. The authors, whose works received the highest number of citations include: H. Jenkins from Cardiff University, the United Kingdom, N. Yakovleva from Newcastle University, the United Kingdom, J.P. Doh from Villanova University, the United States and T.R. Guay from Pennsylvania State University, the United States.

The third study question (What are the most popular contexts of CSR studies employing case study methodology?) focuses attention on countries, industries, and company types, where CSR case studies are conducted. Regarding the geographical context, CSR case studies most 
often refer to developing countries in Asia, Africa and Latin America, but developed countries e.g. Australia and European nations are represented among them as well. The following countries are listed among the top high-frequency keywords: China, India, Brazil, the United Kingdom, Australia, Bangladesh, and Spain. In regard to the industrial context, the mining industry seems to be the sector attracting the most attention of researchers. Other industries which are often analysed in CSR studies include: tourism and hospitality, food, banking and financial services, chemical, forestry, manufacturing, public health, fashion and textile, oil industries. In regard to the company type, CSR case studies are most often interested in international/multinational companies, small and medium enterprises (SMEs) and family businesses.

Through bibliometric analysis of case studies in corporate social responsibility, the study contributes first and foremost to management theory. Firstly, it provides the scholars interested in the field with a detailed map identifying key contributors (countries, research institutions and authors), which may be useful for establishing research collaboration. Secondly, analysing leading source titles is of high practical value for the authors considering journals for submitting their works. Finally, discovering the most often explored contexts of CSR case studies (in regard to geography, industries, and company types), on the one hand, indicates main research interests in the field, but on the other hand may be an indication to find interesting gaps to be covered in prospective case studies. The originality of the study derives from the fact that scientific output including CSR related case studies has not been mapped, so far. The employed methodology, including combination of the bibliometric descriptive approach represented by the research profiling framework and quantitative science mapping methods (citation and co-authorship analysis) creates the unique value of the study.

Discussing the findings of the analysis, limitations of the study should be made explicit. Firstly, appreciating the strengths of research profiling and science mappings methods, it needs to be highlighted that bibliometric methodology is well suited for conducting quantitative analysis of large sets of data related to research publication, but it lacks a 'deep dive' into the analysed topics. Thus, it is recommended to continue the exploration of CSR related case studies with systematic literature reviews (Czakon, 2011; Tranfield et al., 2003). For instance, investigating the reasons for scholars' preference to employ case studies 
in particular contexts of geography, industry and company type seems to be a very promising topic for thorough systematic literature reviews. Secondly, although Scopus is a highly recognized source of high quality bibliometric data, it is very biased towards publications written in English. In consequence, some valuable studies, especially those written in languages other than English, may have been omitted in the research sampling process. Therefore, replication of research profiling based on other sources of data is suggested. Finally, the study included only some aspects of science mapping methods, i.e. citation analysis and co-authorship analysis, to support research profiling. It means that there are still interesting topics worth of being explored with the use of bibliometrics. The examples are: citation analysis aimed at exploring the core references or co-word analysis of high-frequency keywords aimed at discovering leading thematic areas or emerging topics.

\section{References}

Andersen, M., \& Skjoett-Larsen, T. (2009). Corporate social responsibility in global supply chains. Supply Chain Management: An International Journal, 14(2), 75-86. https://doi.org/10.1108/13598540910941948

Brice, H., \& Wegner, T. (1989). A quantitative approach to corporate social responsibility programme formulation. Managerial and Decision Economics, 10(2), 163-171. https://doi.org/10.1002/mde.4090100213

Ciliberti, F., Pontrandolfo, P., \& Scozzi, B. (2008). Investigating corporate social responsibility in supply chains: A SME perspective. Journal of Cleaner Production, 16(15), 1579-1588. https://doi.org/10.1016/j.jclepro.2008.04.016

Czakon, W. (2011). Metodyka systematycznego przeglądu literatury. Przeglq̨d Organizacji, 3, 57-61. https://doi.org/doi:10.33141/po.2011.03.13.

Doh, J. P., \& Guay, T. R. (2006). Corporate social responsibility, public policy, and NGO activism in Europe and the United States: An institutional-stakeholder perspective. Journal of Management Studies, 43(1), 47-73. https://doi.org/10.1111/j.1467-6486. 2006.00582. $\mathrm{x}$

Herrera, J., \& de las Heras-Rosas, C. (2020). Corporate social responsibility and human resource management: Towards sustainable business organizations. Sustainability (Switzerland), 12(3). https://doi.org/10.3390/su12030841

Jenkins, H. (2004). Corporate social responsibility and the mining industry: Conflicts and constructs. Corporate Social Responsibility and Environmental Management, 11(1), 23-34. https://doi.org/10.1002/csr.50

Jenkins, H. (2006). Small business champions for corporate social responsibility. Journal of Business Ethics, 67(3), 241-256. https://doi.org/10.1007/s10551-006-9182-6

Jenkins, H., \& Yakovleva, N. (2006). Corporate social responsibility in the mining industry: Exploring trends in social and environmental disclosure. Journal of Cleaner Production, 14(3-4), 271-284. https://doi.org/10.1016/j.jclepro.2004.10.004 
Jones, P., \& Comfort, D. (2019). Storytelling and corporate social responsibility reporting: A case study commentary on U.K. food retailers. Journal of Public Affairs, 19(4). https://doi.org/10.1002/pa.1834

Jones, P., Comfort, D., \& Hillier, D. (2005). Corporate social responsibility as a means of marketing to and communicating with customers within stores: A case study of UK food retailers. Management Research News, 28(10), 47-56. https://doi.org/ 10.1108/01409170510785011

Jones, P., Comfort, D., \& Hillier, D. (2006a). Healthy eating and the UK's major food retailers: A case study in corporate social responsibility. British Food Journal, 108(10), 838-848. https://doi.org/10.1108/00070700610702091

Jones, P., Comfort, D., \& Hillier, D. (2006b). Reporting and reflecting on corporate social responsibility in the hospitality industry: A case study of pub operators in the UK. International Journal of Contemporary Hospitality Management, 18(4), 329-340. https://doi.org/10.1108/09596110610665339

Jones, P., Comfort, D., \& Hillier, D. (2007a). Marketing and corporate social responsibility within food stores. British Food Journal, 109(8), 582-593. https:// doi.org/10.1108/00070700710772381

Jones, P., Comfort, D., \& Hillier, D. (2007b). Corporate social responsibility: A case study of the top ten global retailers. EuroMed Journal of Business, 2(1), 23-35. https://doi.org/10.1108/14502190710749938

Jones, P., Comfort, D., \& Hillier, D. (2008). Corporate social responsibility and marketing communications within stores: A case study of U.K. food retailers. Journal of Food Products Marketing, 14(4), 109-119. https://doi.org/10.1080/10454440801987908

Jones, P., Comfort, D., Hillier, D., \& Eastwood, I. (2005). Corporate social responsibility: A case study of the UK's leading food retailers. British Food Journal, 107(6), 423-435. https://doi.org/10.1108/00070700510602192

Jones, P., Hillier, D., \& Comfort, D. (2009). Corporate social responsibility in the UK gambling industry. Corporate Governance, 9(2), 189-201. https://doi.org/10.1108/ 14720700910946622

Jones, P., Hillier, D., \& Comfort, D. (2012). Fashioning corporate social responsibility. Emerald Emerging Markets Case Studies, 2(8), 1-10. https://doi.org/10.1108 /20450621211295578

Lis, A. (2018). Profiling and mapping the contexts of the case study research in business, management and accounting. International Journal of Contemporary Management, 17(1), 179-196. https://doi.org/doi:10.4467/24498939IJCM.18.010.8389

Lis, A., \& Cegliński, P. (2017). General research profiling for the role of leadership in corporate social responsibility. Marketing i Rynek, 11 (CD), 321-332.

Martinez, H., Jaime, A., \& Camacho, J. (2012). Relative absorptive capacity: A research profiling. Scientometrics, 92(3), 657-674. https://doi.org/10.1007/s11192-0 12-0652-6

Mongeon, P., \& Paul-Hus, A. (2016). The journal coverage of Web of Science and Scopus: A comparative analysis. Scientometrics, 106(1), 213-228. https://doi. org/10.1007/s11192-015-1765-5

Porter, A. L., Kongthon, A., \& Lu, J.-C. C. (2002). Research profiling: Improving the literature review. Scientometrics, 53(3), 351-370. https://doi.org/10.1023/A:1014 873029258 
Preslmayer, C., Kuttner, M., \& Feldbauer-Durstmüller, B. (2018). Uncovering the research field of corporate social responsibility in family firms: A citation analysis. Journal of Family Business Management, 8(2), 169-195. https://doi.org/10.1108/ JFBM-10-2017-0032

Schotten, M., El Aisati, M., Meester, W. J. N., Steiginga, S., \& Ross, Cameron, A. (2017). A brief history of Scopus: The world's largest abstract and citation database of scientific literature. In F. J. Cantú-Ortiz (Ed.), Research Analytics: Boosting University Productivity and Competitiveness through Scientometrics (pp. 31-58). Auerbach Publications. https://doi.org/https://doi.org/10.1201/9781315155890

Scopus Content Coverage Guide 2020. (2020). https://www.elsevier.com/_data/assets/ pdf_file/0007/69451/Scopus_ContentCoverage_Guide_WEB.pdf

Sudolska, A., \& Lis, A. (2018). Profiling research on a sustainable enterprise and a sustainable organization. Zeszyty Naukowe Politechniki Śląskiej: Organizacja i Zarzqdzanie, 127, 263-272.

Sudolska, A., Lis, A., \& Chodorek, M. (2019). Research profiling for responsible and sustainable innovations. Sustainability, 11(23), art. 6553. https://doi.org/10.3390/ su11236553

Tranfield, D., Denyer, D., \& Smart, P. (2003). Towards a methodology for developing evidence-informed management knowledge by means of systematic review. British Journal of Management, 14(3), 207-222. https://doi.org/10.1111/1467-8551.00375

van Eck, N. J., \& Waltman, L. (2010). Software survey: VOSviewer, a computer program for bibliometric mapping. Scientometrics, 84(2), 523-538. https://doi.org/ 10.1007/s11192-009-0146-3

van Eck, N. J., \& Waltman, L. (2018). VOSviewer Manual. Universiteit Leiden. https:// www.vosviewer.com/documentation/Manual_VOSviewer_1.6.9.pdf

Zhu, J., \& Liu, W. (2020). A tale of two databases: The use of Web of Science and Scopus in academic papers. Scientometrics, 123(1), 321-335. https://doi.org/10.10 07/s11192-020-03387-8

Zupic, I., \& Čater, T. (2015). Bibliometric methods in management and organization. Organizational Research Methods, 18(3), 429-472. https://doi.org/10.1177/109 4428114562629 